Leo J. Ostruszka · Donna S. Shewach

\title{
The role of DNA synthesis inhibition in the cytotoxicity of $2^{\prime}, 2^{\prime}$-difluoro-2'-deoxycytidine
}

Received: 26 December 2002/ Accepted: 2 May 2003/Published online: 17 June 2003

(C) Springer-Verlag 2003

\begin{abstract}
Purpose: Cytotoxicity from the anticancer drug $2^{\prime}, 2^{\prime}$-difluoro-2'-deoxycytidine (dFdCyd) has been correlated with its incorporation into DNA. However, cytotoxicity may also result from inhibition of DNA synthesis, due to either (1) dFdCyd diphosphate-mediated inhibition of ribonucleotide reductase, or (2) direct inhibition of DNA polymerases by the $5^{\prime}$-triphosphate of dFdCyd (dFdCTP). To elucidate the role of DNA synthesis inhibition in the cytotoxicity of $\mathrm{dFdCyd}$, we compared dFdCyd to hydroxyurea (HU), a ribonucleotide reductase inhibitor, and aphidicolin, an inhibitor of DNA polymerases, in the U251 and D54 human glioblastoma cell lines. Methods: Sensitivity to dFdCyd, $\mathrm{HU}$, and aphidicolin were determined using a colony formation assay. The effects of these drugs on DNA synthesis were measured by dual parameter flow cytometry, while the effects on nucleotide pool levels were analyzed by high-performance liquid chromatography. Results: HU and aphidicolin elicited substantially less cytotoxicity than the multi-log killing with $\mathrm{dFdCyd}$. When used at equitoxic concentrations (24-h $\mathrm{IC}_{50}$ values), dFdCyd and HU decreased purine dNTP pools primarily, but dFdCyd was less effective than $\mathrm{HU}$. dFdCyd had decreased dATP by about $80 \%$ after 4 $12 \mathrm{~h}$, and required 8-24 h to decrease DNA synthesis by $50 \%$. In contrast, HU rapidly depleted dATP by $>98 \%$ within $2 \mathrm{~h}$, which resulted in $>90 \%$ inhibition of DNA synthesis. Aphidicolin at a concentration similar to its $\mathrm{K}_{\mathrm{i}}$ values for DNA polymerases $(1 \mu M)$ decreased DNA synthesis by $>70 \%$ within $2 \mathrm{~h}$. However, this decreased cell survival by only 10\% (U251 cells) and 40\% (D54 cells). Conclusions: These results demonstrate that HU and aphidicolin produced a more rapid and profound inhibition of DNA synthesis than $\mathrm{dFdCyd}$, but resulted
\end{abstract}

L. J. Ostruszka · D. S. Shewach $(\bowtie)$

Department of Pharmacology,

University of Michigan Medical Center,

1310 E. Catherine St., Ann Arbor, MI 48109-0504, USA

E-mail: dshewach@umich.edu

Tel.: + 1-734-7635810

Fax: +1-734-7633438 in significantly less cytotoxicity. This suggests that inhibition of DNA synthesis accounted for less than one $\log$ of the multi-log cytotoxicity observed with dFdCyd, whereas incorporation of $\mathrm{dFdCTP}$ into DNA is a more lethal event.

Keywords dFdCyd - DNA synthesis $\cdot$ dNTP Ribonucleotide reductase

\section{Introduction}

Many anticancer nucleoside analogs, such as cytosine arabinoside, cladribine, 2',2'-difluoro-2'-deoxycytidine $(\mathrm{dFdCyd})$, and fludarabine, share a common mechanism of cytotoxicity that targets DNA synthesis [35]. After phosphorylation to a $5^{\prime}$-triphosphate derivative, nucleoside analogs can interfere with DNA synthesis by: (1) direct inhibition of DNA polymerases, and (2) slowing of DNA elongation or chain termination after insertion into DNA [5, 10, 15, 26, 32, 38, 50]. For some nucleoside analogs, the incorporation of their $5^{\prime}$-triphosphates into DNA has been correlated with their cytotoxicity [21, 23, 41, 51].

In addition to direct effects on DNA synthesis, some nucleoside derivatives have been shown to inhibit ribonucleotide reductase, but the role this plays in overall cytotoxicity is not well understood $[4,14,16,28,29,33$, $34,46,50]$. Ribonucleotide reductase is responsible for the de novo biosynthesis of deoxyribonucleoside triphosphates (dNTPs) necessary for DNA synthesis in mammalian cells [22]. Inhibition of ribonucleotide reductase results in selective decreases in endogenous dNTPs, depending on the cell line $[16,40,46]$. An important result of the decrease in endogenous dNTP pools is that it can lessen competition against the nucleotide analog for incorporation into DNA, thus leading to greater cytotoxicity. This process is known as "selfpotentiation," and is likely a key factor in the cytotoxicity of several clinically active nucleoside analogs such as fludarabine, cladribine, and dFdCyd [6, 14, 17, 36]. 
Other anticancer drugs, such as hydroxyurea (HU), 5-fluoro-2'-deoxyuridine, methotrexate, and $\mathrm{N}$-phosphonacetyl-L-aspartate (PALA), elicit cytotoxicity primarily through the alteration of dNTP pools $[1,9,12$, 37]. As expected, these drugs also inhibit DNA synthesis. The role of decreased dNTP pools has become more interesting with the finding that nucleoside analogs and other drugs that inhibit ribonucleotide reductase can enhance the effects of ionizing radiation $[13,27,39,45,46,47,48,49]$. The clinically important drugs HU and $\mathrm{dFdCyd}$ have the ability to inhibit ribonucleotide reductase, either directly as a free radical scavenger [22], or mechanistically as the 5'-diphosphate derivative of $\mathrm{dFdCyd}$ ( $\mathrm{dFdCDP}$ ) [2]. Previous studies in this and other laboratories have associated ribonucleotide reductase inhibition with radiosensitization by both agents [46, 47]. In contrast, the cytotoxicity by $\mathrm{dFdCyd}$ has been correlated with its incorporation into DNA [21]. However, incorporation into DNA and inhibition of ribonucleotide reductase are interrelated processes, since the level of the 5'-triphosphate of dFdCyd (dFdCTP) determines the extent of DNA incorporation, and the amount of dFdCDP is related to the amount of $\mathrm{dFdCTP}[15,21]$. This makes it difficult to distinguish the impact of each pathway individually on cytotoxicity.

In solid tumor cells, it is particularly important to evaluate the role of ribonucleotide reductase inhibition in the action of $\mathrm{dFdCyd}$ since non-cytotoxic concentrations can produce profound decreases in dATP [25, 46]. Therefore, we compared the effects of dFdCyd on DNA synthesis with the ribonucleotide reductase inhibitor HU, and with aphidicolin, which directly inhibits replicative DNA polymerases without affecting the dNTP pools [43]. The results demonstrated that perturbation of dNTP pools or direct polymerase inhibition contributes primarily to the inhibition of DNA synthesis without a major effect on cytotoxicity. A preliminary account of a portion of these results has been reported in abstract form [30].

\section{Materials and methods}

\section{Chemicals}

dFdCyd and dFdCTP were synthesized and generously provided by Eli Lilly and Co. (Indianapolis, Ind.). RNase A was purchased from Boehringer Mannheim (Indianapolis, Ind.). HU, propidium iodide, and nucleotide standards were all purchased from Sigma Chemical Company (St. Louis, Mo.).

\section{Cell culture}

The human glioblastoma cell lines U251 and D54 were cultured in RPMI 1640 medium supplemented with $10 \%$ calf serum (GIBCO, Grand Island, N.Y.) and L-glutamine (Fisher Scientific, Pittsburgh, $\mathrm{Pa}$.). Cells were maintained in exponential growth in a humidified atmosphere containing $5 \% \mathrm{CO}_{2}$ at $37^{\circ} \mathrm{C}$.

\section{Cytotoxicity assays}

Cytotoxicity was measured using a standard colony formation assay. Cell culture flasks $\left(25 \mathrm{~cm}^{2}\right)$ were plated with between $3 \times 10^{5}$ and $6 \times 10^{5}$ cells a minimum of $36 \mathrm{~h}$ prior to addition of drug. Exponentially growing cells were incubated with drug for $24 \mathrm{~h}$. At the conclusion of the drug incubation period, cells were washed with Dulbecco's PBS (phosphate-buffered saline), trypsinized, and counted using a Coulter (Hialeah, Fl.) electronic particle counter Approximately 100 viable cells were plated into each $35-\mathrm{mm}$ diameter well of a six-well culture dish and allowed to grow in the absence of drug for 10-14 days. At that time, the resulting colonies were fixed using a methanol/glacial acetic acid solution $(3: 1 \mathrm{v} / \mathrm{v})$ and stained with $0.4 \%$ crystal violet. Colonies of more than 30 cells were counted and survival was determined as a fraction of plating efficiency of untreated control cells.

\section{Analysis of dNTP pools}

Cells were incubated with drug for 1-24 h, harvested by trypsinization, and counted. The nucleotides were extracted with ice-cold $0.4 N$ perchloric acid and neutralized with $10 \mathrm{~N}$ potassium hydroxyide. The majority of the ribonucleotides were removed from the deoxyribonucleotides by elution over a boronate affinity column as described previously [44]. Deoxyribonucleotides were separated and quantitated by strong anion exchange high-performance liquid chromatography (HPLC) using a Waters Alliance (Milford, Mass.) gradient system equipped with a model 996 photodiode array detector and controlled by Millennium 2010 software. Before injection, each sample was centrifuged at $16,000 \mathrm{~g}$ for $2 \mathrm{~min}$ and acidified to $\mathrm{pH}$ 2.8. Samples were then injected onto a 5- $\mu \mathrm{m}$ Partisphere $4.6 \times 250 \mathrm{~mm}$ SAX column (Whatman Scientific, Hillsboro, Ore.) and eluted with a linear gradient of ammonium phosphate buffer ranging from $0.15 M(\mathrm{pH} 2.8)$ to $0.6 M(\mathrm{pH} \mathrm{2.8-3.8)}$ at a flow rate of $2 \mathrm{ml} / \mathrm{min}$. Nucleotides were identified and quantitated by comparison to a known amount of authentic standards using their characteristic absorbance spectra over the range $200-350 \mathrm{~nm}$.

\section{DNA synthesis}

Flow cytometric analysis was performed as previously described [31]. Briefly, at the conclusion of the drug incubation, cells were pulse-labeled with $30 \mu M$ bromodeoxyuridine (BrdUrd) for $15 \mathrm{~min}$, and then harvested by trypsinization, counted, and washed with PBS. Cells were then fixed in cold $70 \%$ ethanol at a concentration of $1 \times 10^{7}$ cells $/ \mathrm{ml}$, with samples not to exceed a total of $3 \times 10^{7}$ cells. Fixed cells were stored at $4^{\circ} \mathrm{C}$ for up to 10 days. Within $6 \mathrm{~h}$ prior to flow cytometric analysis, fixed cells were washed with PBS and resuspended in $1 \mathrm{ml}$ PBS containing $0.5 \mathrm{mg} / \mathrm{ml}$ RNase A and incubated for $30 \mathrm{~min}$ at $37^{\circ} \mathrm{C}$. Cells were then washed with PBS, resuspended in $1 \mathrm{ml} 0.1 \mathrm{~N}$ hydrochloric acid containing $0.7 \%$ Triton X-100, and incubated for $10 \mathrm{~min}$ on ice. This was followed by another PBS wash, resuspension in $1 \mathrm{ml}$ sterile HPLC grade water, and incubation at $95^{\circ} \mathrm{C}$ for $15 \mathrm{~min}$. The samples were immediately transferred to an ice-water bath for an additional 15 min. Cells were then washed with PBS containing $0.5 \%$ Tween 20. PBS $(100 \mu \mathrm{l})$ containing $0.5 \%$ Tween 20 and $5 \%$ calf serum was added to each cell pellet followed by the addition of $100 \mu \mathrm{l}$ antiBrdUrd mouse IgG1 antibody (1:100 dilution, BD PharMingen, San Diego, Calif.) and incubation for $30 \mathrm{~min}$ at room temperature. After centrifugation, $150 \mu \mathrm{l}$ FITC-conjugated goat anti-mouse IgG antibody (1:20-35 dilution, Sigma Chemical Company, St. Louis, Mo.) was added to the pellet, mixed gently, and incubated for $30 \mathrm{~min}$ at room temperature. Samples were centrifuged and resuspended in $0.5 \mathrm{ml} 18 \mu \mathrm{g} / \mathrm{ml}$ propidium iodide. Trout erythrocyte nuclei (Biosure, Grass Valley, Calif.) were added as an internal standard. Treated cells were placed in the dark a minimum of 30 min prior to cell cycle analysis using a Coulter EPICS Elite ESP flow cytometer. Cell cycle data were further analyzed using 
WinMDI software (version 2.8.8) provided by Joseph Trotter of the Scripps Research Institute. Percent DNA synthesis was determined by the change in the mean fluorescence intensity of S-phasespecific BrdUrd incorporation in drug-treated in relation to control cells. The Quadstat gate to separate BrdUrd-negative cells and BrdUrd-positive cells was based on a negative fluorescent antibody control.

\section{Results}

\section{Cytotoxicity}

dFdCyd was significantly more potent than $\mathrm{HU}$, with 24-h $\mathrm{IC}_{50}$ values 7,500-120,000 times lower in the U251 and D54 human glioblastoma cell lines (25-80 $\mathrm{n} M$ and 0.6-3 $\mathrm{m} M$ for $\mathrm{dFdCyd}$ and HU, respectively; Fig. 1). Using concentrations of $\mathrm{HU}$ threefold greater than the 24-h $\mathrm{IC}_{50}$ decreased cell survival to about $33 \%$ in U251 and about $23 \%$ in D54 cells, and a tenfold increase killed about $1.5 \operatorname{logs}$ of D54 and $76 \%$ of U251 cells. In contrast, increasing the $\mathrm{dFdCyd}$ concentration threeand tenfold over the 24-h $\mathrm{IC}_{50}$ produced 1-3 logs of cell death in U251 and D54 cells. A similar difference in potency was also observed between $\mathrm{dFdCyd}$ and HU in HT-29 human colon carcinoma cells (data not shown).

\section{Effects on purine dNTP pools}

In solid tumor cells treated with ribonucleotide reductase inhibitors, dATP is depleted more rapidly and to a greater extent compared to the other dNTPs $[25,46]$. Similarly, in the studies presented here both $\mathrm{dFdCyd}$ and $\mathrm{HU}$ produced decreases primarily in the dATP pool. As shown in Table 1, dFdCyd (24-h $\mathrm{IC}_{50}$ ) decreased dATP levels within $2 \mathrm{~h}$ after drug addition by $<50 \%$ in U251 and D54 cells, and dATP continued to decrease throughout the incubation period reaching its lowest value by $24 \mathrm{~h}$. Significantly higher

Table 1 Perturbation of dNTP pools by inhibitors of ribonucleotide reductase in U251 and D54 cells. Exponentially growing cells were treated with either $25 \mathrm{n} M$ or $80 \mathrm{n} M$ dFdCyd (24-h IC 50 values) or $0.6 \mathrm{~m} M$ or $3 \mathrm{~m} M$ HU (24-h $\mathrm{IC}_{50}$ values). Nucleotides were extracted with perchloric acid, eluted over a boronate affinity column to reduce ribonucleotides, and separated and quantitated using
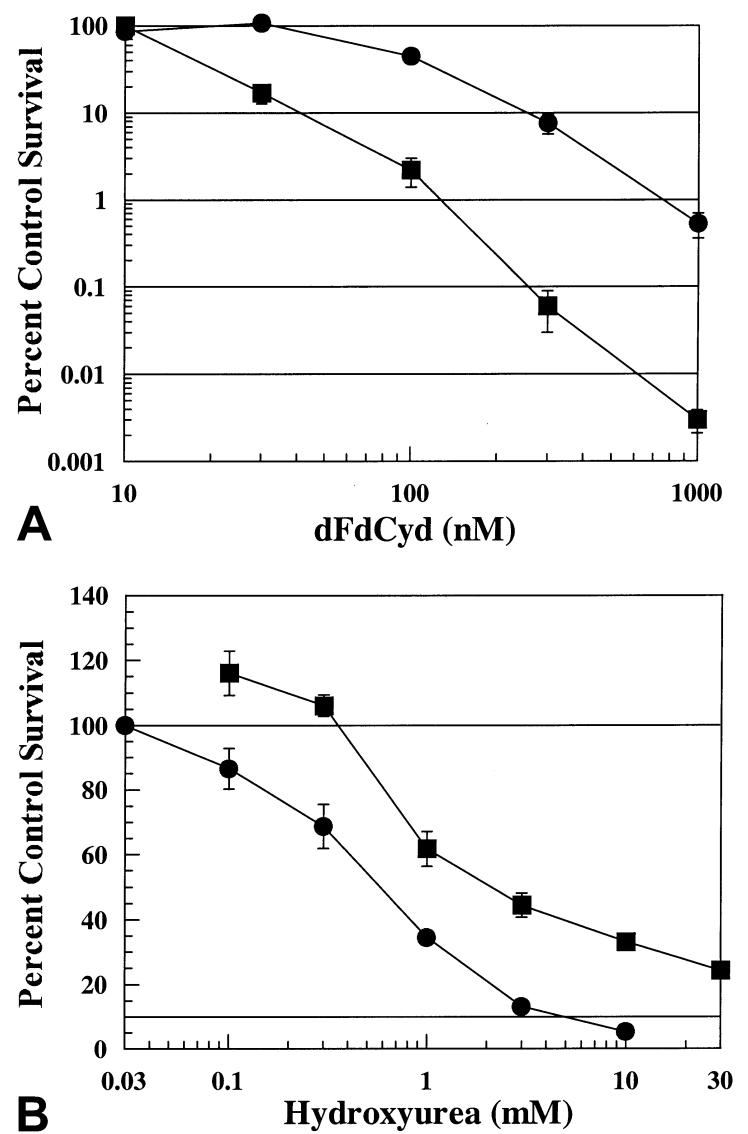

Fig. 1A, B Comparison of cytotoxicity of dFdCyd (A) and HU (B) in human glioblastoma cells. U251 (ם) or D54 (O) cells were treated with drug for $24 \mathrm{~h}$ and assayed for clonogenic survival. The values shown are the means $\pm \mathrm{SE}$ of triplicate determinations from a single experiment. Experiments were repeated at least three times

concentrations of $\mathrm{dFdCyd}(0.4 \mu M$ in $\mathrm{U} 251,4.0 \mu M$ in D54) were required to deplete dATP in both cell lines to less than $5 \%$ of control levels within $4 \mathrm{~h}$ (data not shown). In contrast, the $24-\mathrm{h} \mathrm{IC}_{50}$ doses of $\mathrm{HU}$

HPLC. Data represent the means \pm SD of one to four determinations. $100 \%$ levels of dNTPs in U251 cells are (nmol $/ 10^{7}$ cells) dATP 0.171, dGTP 0.099, dCTP 0.412, and dTTP 0.748; and in D54 cells are dATP 0.341 , dGTP 0.105 , dCTP 0.479 , and dTTP 1.384

\begin{tabular}{|c|c|c|c|c|c|c|c|c|c|}
\hline \multirow[t]{2}{*}{ Inhibitor } & \multirow[t]{2}{*}{ Time (h) } & \multicolumn{2}{|c|}{ dATP (\%) } & \multicolumn{2}{|c|}{ dGTP (\%) } & \multicolumn{2}{|c|}{ dCTP (\%) } & \multicolumn{2}{|c|}{ dTTP (\%) } \\
\hline & & U251 & D54 & U251 & D54 & U251 & D54 & U251 & D54 \\
\hline \multirow[t]{5}{*}{ dFdCyd } & 0 & 100 & 100 & 100 & 100 & 100 & 100 & 100 & 100 \\
\hline & 2 & $53.6 \pm 9.6$ & $87.2 \pm 7.0$ & $87.4 \pm 17.9$ & $118.5 \pm 42.2$ & $73.3 \pm 12.5$ & $102.9 \pm 5.3$ & $74.9 \pm 19.7$ & $90.6 \pm 14.9$ \\
\hline & 4 & $19.2 \pm 11.1$ & $60.5 \pm 11.5$ & $61.4 \pm 11.1$ & $75.2 \pm 16.3$ & $64.6 \pm 1.0$ & 105.7 & $86.2 \pm 17.2$ & $79.8 \pm 16.1$ \\
\hline & 12 & $6.9 \pm 5.9$ & $21.6 \pm 9.0$ & $54.1 \pm 20.9$ & $84.5 \pm 10.7$ & $117.6 \pm 18.0$ & $88.7 \pm 7.0$ & $85.8 \pm 15.6$ & $68.6 \pm 6.8$ \\
\hline & 24 & $0.7 \pm 0.6$ & $15.0 \pm 10.3$ & $44.5 \pm 38.8$ & $85.7 \pm 25.4$ & $149.4 \pm 83.4$ & $130.6 \pm 1.1$ & $120.5 \pm 61.4$ & $79.8 \pm 21.0$ \\
\hline \multirow[t]{5}{*}{$\mathrm{HU}$} & 0 & 100 & 100 & 100 & 100 & 100 & 100 & 100 & 100 \\
\hline & 2 & $0.9 \pm 1.3$ & $1.7 \pm 2.0$ & $23.3 \pm 8.4$ & $39.9 \pm 16.9$ & $93.3 \pm 1.5$ & $74.7 \pm 3.1$ & $130.8 \pm 40.2$ & $109.4 \pm 14.4$ \\
\hline & 4 & $1.6 \pm 1.8$ & $1.7 \pm 2.1$ & $24.4 \pm 10.0$ & $40.4 \pm 14.3$ & $132.3 \pm 2.8$ & $84.8 \pm 7.7$ & $140.3 \pm 5.1$ & $111.7 \pm 13.3$ \\
\hline & 12 & $0.7 \pm 0.9$ & $1.2 \pm 2.1$ & $25.5 \pm 2.7$ & $82.9 \pm 23.1$ & $186.7 \pm 3.1$ & $142.2 \pm 12.4$ & $152.7 \pm 35.2$ & $163.1 \pm 23.9$ \\
\hline & 24 & $0.7 \pm 0.9$ & $8.4 \pm 5.5$ & $38.0 \pm 6.7$ & $142.4 \pm 43.1$ & $177.4 \pm 10.4$ & $261.6 \pm 31.5$ & $175.7 \pm 31.4$ & $213.8 \pm 62.8$ \\
\hline
\end{tabular}


rapidly decreased dATP in both cell lines, achieving values of less than $2 \%$ of control within $2 \mathrm{~h}$ of drug addition in both cell lines. The dGTP pool was also decreased by both drugs in the two cell lines, although to a lesser extent compared to dATP. Upon closer inspection, it was noted that the rate and extent of dGTP depletion was different between the two agents. $\mathrm{dFdCyd}$ required 4-12 h to deplete dGTP to its lowest level $54 \%$ of control in U251 cells and $75 \%$ in D54 cells). In contrast, HU depleted dGTP to $23 \%$ of control in U251 cells and to $40 \%$ in D54 cells within $2 \mathrm{~h}$ of drug addition. However, by $12 \mathrm{~h}$, dGTP in D54 cells had recovered to $83 \%$ of control, and by $24 \mathrm{~h}$ had increased further to $142 \%$ of control. In U251 cells, the recovery of dGTP in the presence of HU was minimal with only $38 \%$ of control levels present after $24 \mathrm{~h}$. These data also highlight the fact that, although $\mathrm{IC}_{50}$ doses were used for both drugs, the effects on the purine dNTP pools were more marked in the U251 than in the D54 cells.

Effects on pyrimidine dNTP pools

After treatment with either dFdCyd or HU, the pyrimidine dNTP pools exhibited a markedly different pattern from the purine dNTP pools. U251 and D54 cells showed little or no changes in dCTP during the first $4 \mathrm{~h}$ after addition of dFdCyd or HU (Table 1). However, by the end of $24 \mathrm{~h}$, dCTP levels in both cell lines had increased to $131 \%-262 \%$ of their initial values. Treatment with $\mathrm{dFdCyd}$ only produced marginal changes in the dTTP pool in the two cell lines during the $24 \mathrm{~h}$ incubation (Table 1). In contrast, HU treatment increased dTTP levels within $2 \mathrm{~h}$, and dTTP continued to increase achieving final levels of $176 \%$ and $214 \%$ of control values in U251 and D54 cells, respectively, after $24 \mathrm{~h}$. It should be noted that the cell numbers did not decrease during drug treatment. This indicated that the increase in pyrimidines observed was not the result of salvage from lysed cells.

\section{Accumulation of dFdCTP}

During a 24-h incubation with equitoxic doses of dFdCyd (24-h $\mathrm{IC}_{50}$ ), accumulation of dFdCTP was similar in the two cell lines (Fig. 2). dFdCTP levels increased during the first $12 \mathrm{~h}$, when they appeared to reach a plateau with concentrations of $0.06 \mathrm{nmol} / 10^{7}$ cells in U251 cells and $0.05 \mathrm{nmol} / 10^{7}$ cells in D54 cells. We have previously reported that D54 cells incorporate $0.57 \mathrm{nmol} / 10^{7}$ cells of $\mathrm{dFdCMP}$ and U251 cells incorporate $0.40 \mathrm{nmol} / 10^{7}$ cells of $\mathrm{dFdCMP}$ under these conditions [31]. Thus, although the $\mathrm{IC}_{50}$ doses for these cell lines differed by more than threefold, the amount of $\mathrm{dFdCTP}$ and the level of its incorporation into DNA were similar under equitoxic conditions.

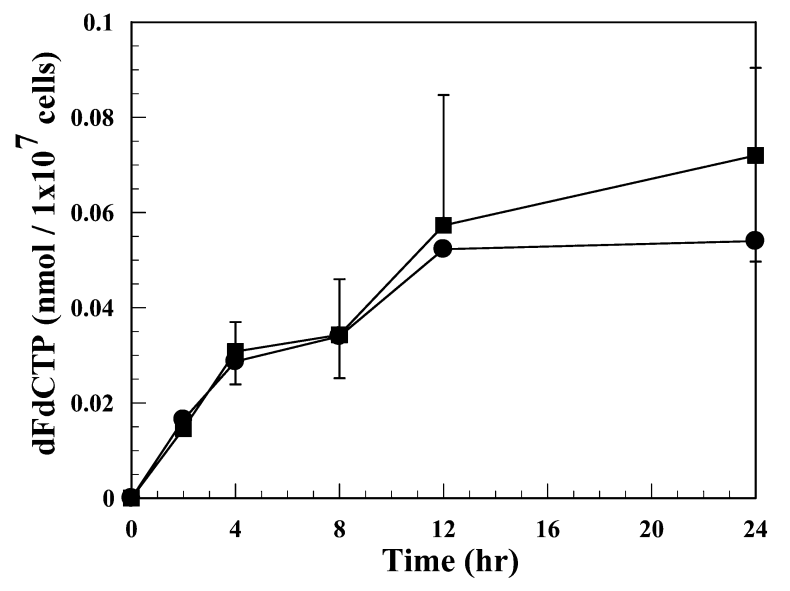

Fig. 2 Accumulation of $\mathrm{dFdCTP}$ in U251 and D54 human glioblastoma cells. Exponentially growing U251 (a) or D54 (O) cells were treated with $25 \mathrm{nM}$ and $80 \mathrm{nM}$ dFdCyd (24-h IC 50 values for U251 and D54, respectively). Nucleotides were extracted with perchloric acid and separated using HPLC. The values shown are the means $\pm \mathrm{SE}$ from two to four determinations (error bars are shown only in the up direction or down direction for U251 and D54 cells, respectively)

\section{Inhibition of DNA synthesis}

In order to determine whether these equitoxic conditions produced similar effects on DNA synthesis, we compared the ability of each drug to inhibit DNA synthesis as measured by BrdUrd incorporation and flow cytometric analysis. S-phase cells were identified by their ability to incorporate BrdUrd, and the mean fluorescence intensity of drug-treated cells compared to control cells yielded the percent control DNA synthesis values. During a $24-\mathrm{h} \quad \mathrm{IC}_{50}$ incubation with $\mathrm{dFdCyd}(25 \mathrm{n} M$ and $80 \mathrm{n} M$ for $\mathrm{U} 251$ and D54, respectively), neither cell line showed a decrease in DNA synthesis within the first $2 \mathrm{~h}$ (Fig. 3A). After $4 \mathrm{~h}$, DNA synthesis had decreased to $61 \%$ in U251 cells, whereas D54 cells showed no inhibition. DNA synthesis decreased in both cell lines between 8 and $24 \mathrm{~h}$, at which time it achieved its lowest levels $(18 \%$ in U251 cells and $48 \%$ in D54 cells). Measurement of DNA synthesis using $\left[{ }^{3} \mathrm{H}\right]$ thymidine incorporation produced similar results (data not shown).

In contrast to $\mathrm{dFdCyd}, \mathrm{HU}\left(24-\mathrm{h} \mathrm{C}_{50}\right)$ produced a more rapid inhibition of DNA synthesis. Within $2 \mathrm{~h}$ of the addition of HU, DNA synthesis was reduced to $<2 \%$ of control activity in U251 cells and to $<9 \%$ of control in D54 cells (Fig. 3B). In U251 cells, DNA synthesis was inhibited by $>95 \%$ throughout the entire 24-h HU exposure. In D54 cells, the level of DNA synthesis had begun to recover by $8 \mathrm{~h}$ and had returned to $30 \%$ of control by $24 \mathrm{~h}$. These effects on DNA synthesis appear to reflect the effects on the purine dNTP pools, which were depleted faster and to a greater extent with $\mathrm{HU}$ than with $\mathrm{dFdCyd}$. 

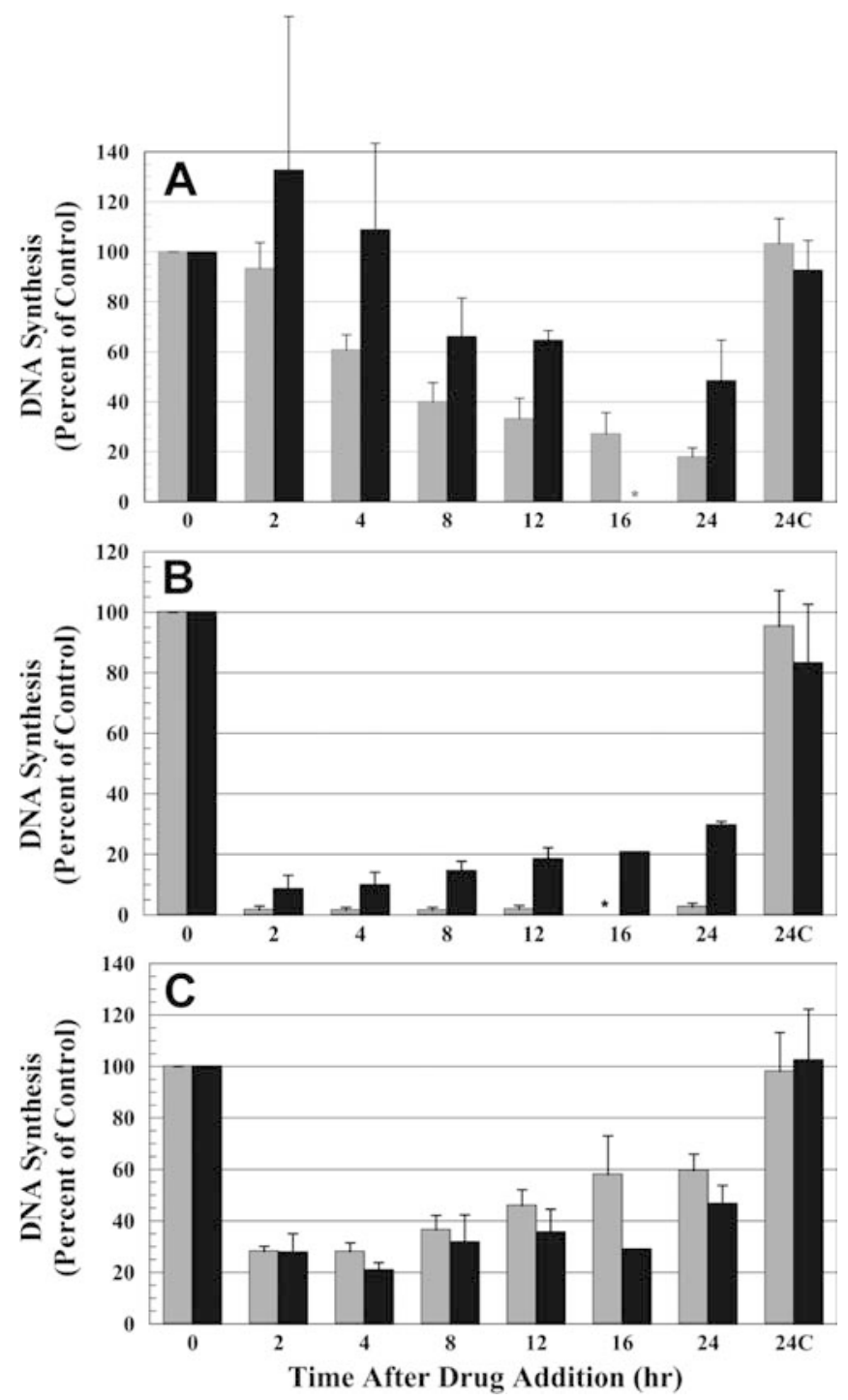

Fig. 3 Effects of dFdCyd (A), HU (B), and aphidicolin (C) on DNA synthesis. Exponentially growing U251 cells (gray bars) or D54 cells (black bars) were treated with $\mathrm{dFdCyd}$ or $\mathrm{HU}$ at their respective $\mathrm{IC}_{50}$ values, or $1 \mu M$ aphidicolin. At the indicated times, cells were incubated with $30 \mu M$ BrdUrd for $15 \mathrm{~min}$ prior to harvest. Cells were prepared as described in Materials and methods and the BrdUrd content was measured in terms of FITCconjugated BrdUrd fluorescence. DNA synthesis inhibition was determined by the change in mean fluorescence in BrdUrdincorporating cells. The data are presented as means $\pm \mathrm{SE}$ of three determinations (*not done)

\section{Effects of aphidicolin}

Aphidicolin inhibits replicative DNA polymerases without any effect on ribonucleotide reductase [43]. Thus, aphidicolin was used to evaluate the effect of DNA polymerase inhibition alone in the absence of fraudulent nucleotide incorporation or ribonucleotide reductase inhibition. Both cell lines were treated with $1 \mu M$ aphidicolin for $24 \mathrm{~h}\left(\mathrm{U} 251 \mathrm{IC}_{10}, \mathrm{D} 54 \mathrm{IC}_{40}\right)$ and DNA synthesis was measured. DNA synthesis decreased rapidly in both cell lines. Within $1 \mathrm{~h}$, DNA synthesis decreased to $40 \%$ and $25 \%$ of control activity in U251 and D54 cells, respectively (data not shown). DNA synthesis continued to decrease throughout the first $4 \mathrm{~h}$ with minimum levels of $28 \%$ in U251 and $21 \%$ in D54 cells (Fig. 3C). By $24 \mathrm{~h}$, U251 cells had recovered to $60 \%$ of control DNA synthesis and D54 cells had recovered to $47 \%$ of control.

\section{Discussion}

Typically, the ability of a nucleoside analog to be incorporated into DNA has been associated with its ability to produce cytotoxicity [21, 23, 35]. Incorporation of analogs can lead to inhibition of DNA synthesis by several mechanisms such as chain termination, difficulty extending DNA due to an altered strand conformation, and repetitive attempts to remove the nucleotide from the DNA strand $[10,20,21,26,32,33,35,38,42$, 50]. However, nucleoside analogs such as dFdCyd, cladribine, and fludarabine all have additional effects on DNA synthesis due to their ability to inhibit ribonucleotide reductase $[6,16]$. Although the effects that these agents have on dNTP pools and DNA polymerases are well documented, the relative contribution of these effects on DNA synthesis and cytotoxicity is not clear. In the study reported here, we attempted to separate the effects of dFdCTP accumulation and dNTP depletion on DNA synthesis and cytotoxicity by comparing dFdCyd to a pure ribonucleotide reductase inhibitor, $\mathrm{HU}$, and a pure polymerase inhibitor, aphidicolin.

Both cell lines demonstrated marked differences in cytotoxicity and dNTP pool depletion with each drug. At equitoxic concentrations, $\mathrm{HU}$ displayed a more rapid and marked effect on dNTP pools than dFdCyd. The increased time required by $\mathrm{dFdCyd}$ to affect dNTP pools was most likely due to the requirement of $\mathrm{dFdCyd}$ to be phosphorylated in order to inhibit ribonucleotide reductase $[2,16]$. In fact, the majority of the purine dNTP depletion occurred during the first $12 \mathrm{~h}$, paralleling the time required to achieve peak dFdCTP levels. Considering that the peak dFdCTP levels in these studies did not exceed $2 \mu M$ (see below), that dFdCDP levels are typically $5-10 \%$ of the $\mathrm{dFdCTP}$ concentration [15], and that $50 \%$ inhibition of ribonucleotide reductase activity in situ requires $0.3 \mu M \mathrm{dFdCDP}$ [16], the slow decrease in dNTPs with dFdCyd in these studies is reasonable.

As found previously in vitro and in vivo $[3,7,9,11$, $18,24,46]$, inhibition of ribonucleotide reductase in these studies resulted in a selective decrease in the purine dNTP pools with no effect on or an increase in the pyrimidine dNTP pools. Although both dCTP and dTTP were increased by dFdCyd and HU in these studies, it is unlikely that these effects played a major role in the toxicity of these drugs. It has been demonstrated that the increase in dTTP following treatment of 3T6 mouse fibroblasts or V79 Chinese hamster lung cells with $\mathrm{HU}$ is due to an increased uptake of 
pyrimidine deoxyribonucleosides from the medium [3, 19], which may account for the increase in pyrimidine dNTP pools observed here. In the studies presented here, HU produced a greater increase in dCTP and dTTP than $\mathrm{dFdCyd}$ at their $\mathrm{IC}_{50}$ values, and this effect increased at higher $\mathrm{HU}$ (but not $\mathrm{dFdCyd}$ ) concentrations (data not shown), yet HU was less toxic. Thus, the increased pyrimidine dNTP pools did not appear to contribute substantially to cytotoxicity.

The results presented here suggest that the level of DNA synthesis primarily reflected purine dNTP pool depletion. The rapid decrease in dATP and dGTP by HU was associated with an almost complete inhibition of DNA synthesis in U251 cells and a $90 \%$ reduction in D54 cells. The slower decline in the dATP and dGTP pools produced by $\mathrm{dFdCyd}$ paralleled the slow decrease in DNA synthesis. Furthermore, the increase in DNA synthesis observed between 8 and $24 \mathrm{~h}$ in D54 cells treated with HU may be due to the marked recovery of dGTP levels at 12-24 h.

It was unlikely that $\mathrm{dFdCTP}$ had a substantial effect on DNA polymerases because the peak dFdCTP concentrations of 0.06 and $0.05 \mathrm{nmol} / 10^{7}$ cells in U251 and D54 cells, respectively (approximately $1.97 \mu M$ and $1.03 \mu M$ based on average cell volumes), were 45- to 110 -fold lower than the apparent $\mathrm{K}_{\mathrm{i}}$ values for either polymerase $\alpha$ or $\epsilon$ in CEM cells as reported by others [21]. In addition, the levels of dFdCTP in U251 and D54 cells were seven- and tenfold lower, respectively, than the endogenous dCTP present at the beginning of drug treatment, further indicating that this low level of dFdCTP would be a poor competitor with the higher levels of dCTP for DNA polymerases. While the incorporation of dFdCTP into DNA may also contribute to DNA synthesis inhibition, D54 cells incorporate more $\mathrm{dFdCTP}$ into DNA $\left(0.57 \mathrm{nmol} / 10^{7}\right.$ cells $)$ than U251 cells $\left(0.40 \mathrm{nmol} / 10^{7}\right.$ cells $)$ over $24 \mathrm{~h}$ under these conditions [31], yet the level of DNA synthesis at $24 \mathrm{~h}$ was more than twofold higher in D54 cells. Taken together, these results indicate that dNTP perturbation played a greater role in DNA synthesis inhibition than the effects of dFdCTP under the conditions utilized here. Heinemann et al. have shown that the recovery of DNA synthesis after washout of $\mathrm{dFdCyd}$ correlates with the amount of $\mathrm{dFdCTP}$ remaining in $\mathrm{CHO}$ cells [15]. However, dNTP pools, which are directly related to $\mathrm{dFdCDP}$ and, therefore, indirectly related to $\mathrm{dFdCTP}$, were not measured in that study.

Similar to HU, aphidicolin inhibited DNA synthesis within $2 \mathrm{~h}$ of treatment, although the amount of DNA synthesis inhibition was less than that produced by the depletion of dNTPs in response to HU. The degree of inhibition was reasonable considering that the concentration of aphidicolin used was in the reported range of apparent $\mathrm{K}_{\mathrm{i}}$ values for DNA polymerases $\alpha, \delta$, and $\epsilon$ of $0.2-2.2 \mu M[8,43]$. The relative level of aphidicolin with respect to the $\mathrm{K}_{\mathrm{i}}$ values for DNA polymerases was greater than the comparative values for $\mathrm{dFdCTP}$, yet aphidicolin produced a similar amount of inhibition as a $12-16 \mathrm{~h}$ exposure to $\mathrm{dFdCyd}$. This suggests that DNA synthesis inhibition with $\mathrm{dFdCyd}$ is the result of the combined effects of dNTP pool depletion and dFdCTP incorporated into DNA, rather than direct inhibition of polymerases by dFdCTP. Despite a more rapid inhibition of DNA synthesis compared to $\mathrm{dFdCyd}$, aphidicolin was only mildly cytotoxic, further supporting the conclusion that DNA synthesis inhibition alone is not a highly cytotoxic event in these cells.

Direct polymerase inhibition produced by aphidicolin and the rapid depletion of dATP and dGTP produced by HU resulted in a profound inhibition of DNA synthesis, yet these drugs produced a maximum of approximately one-log of cell death at high concentrations. dFdCyd has the ability to produce dNTP depletion as well as direct DNA synthesis inhibition, but at equitoxic concentrations had a lesser effect on DNA synthesis compared to aphidicolin and HU. However, dFdCyd was significantly more cytotoxic than either of the other two drugs. These results taken together suggest that a decrease in dNTP pools and the resulting decrease in DNA synthesis contributed less than one-log of cell death with $\mathrm{dFdCyd}$, and the remaining multiple logs of cell death resulted from the incorporation of dFdCTP into DNA.

Acknowledgements This work was supported in part by grant CA 83081 from the NIH/NCI, the University of Michigan Comprehensive Cancer Center NIH grant CA 46592, the University of Michigan Multipurpose Arthritis Center NIH AR20557, and the University of Michigan Core Flow Cytometry Facility.

\section{References}

1. Ahluwalia GS, Grem JL, Hao Z, Cooney DA (1990) Metabolism and action of amino acid analog anti-cancer agents. Pharmacol Ther 46:243

2. Baker CH, Banzon J, Bollinger JM, Stubbe J, Samano V, Robins MJ, Lippert B, Jarvi E, Resvick R (1991) 2'-Deoxy$2^{\prime}$-methylenecytidine and $2^{\prime}$-deoxy-2',2'-difluorocytidine $5^{\prime}$-diphosphates: potent mechanism-based inhibitors of ribonucleotide reductase. J Med Chem 34:1879

3. Bianchi V, Pontis E, Reichard P (1986) Changes in deoxyribonucleoside triphosphate pools induced by hydroxyurea and their relation to DNA synthesis. J Biol Chem 261:16037

4. Bitonti AJ, Dumont JA, Bush TL, Cashman EA, Cross-Doersen DE, Wright PS, Matthews DP, McCarthy JR, Kaplan DA (1994) Regression of human breast tumor xenografts in response to (E)-2'-deoxy-2'-(fluoromethylene)cytidine, and inhibitor of ribonucleoside diphosphate reductase. Cancer Res 54:1485

5. Carson DA, Wasson DB, Kaye J, Ullman B, Martin DW, Robins RK, Montgomery JA (1980) Deoxycytidine kinasemediated toxicity of deoxyadenosine analogs toward malignant human lymphoblasts in vitro and toward murine L1210 leukemia in vivo. Proc Natl Acad Sci U S A 77:6865

6. Chang C-H, Cheng Y (1980) Effects of deoxyadenosine triphosphate and 9- $\beta$-D-arabinofuranosyladenine 5 -triphosphate on human ribonucleotide reductase from Molt-4F cells and the concept of "self-potentiation". Cancer Res 40:3555

7. Eriksson S, Skog S, Tribukait B, Wallstrom B (1987) Deoxyribonucleoside triphosphate metabolism and the mammalian cell cycle. Exp Cell Res 168:79 
8. Fox G, Popanda O, Edler L, Thielmann HW (1996) Preferential inhibition of DNA polymerases $\alpha, \beta$, and $\epsilon$ from Novikoff hepatoma cells by inhibitors of cell proliferation. J Cancer Res Clinical Oncol 122:78

9. Fox RM (1985) Changes in deoxynucleoside triphosphate pools induced by inhibitors and modulators of ribonucleotide reductase. Pharmacol Ther 30:31

10. Fridland A (1977) Inhibition of deoxyribonucleic acid chain initiation: a new mode of action for $1-\beta-D$-arabinofuranosylcytosine in human lymphoblasts. Biochemistry 16:5308

11. Gandhi V, Plunkett W, Kantarjian H, Talpaz M, Robertson LE, O'Brien S (1998) Cellular pharmacodynamics and plasma pharmacokinetics of parenterally infused hydroxyurea during a phase I clinical trial in chronic myelogenous leukemia. J Clin Oncol 16:2321

12. Goldman ID, Matherly LH (1985) The cellular pharmacology of methotrexate. Pharmacol Ther 28:77

13. Gregoire V, Van NT, Stephens C, Brock WA, Milas L, Plunkett W, Hittelman WN (1994) The role of fludarabineinduced apoptosis and cell cycle synchronization in enhanced murine tumor radiation response in vivo. Cancer Res 54:6201

14. Griffig J, Koob R, Blakely WF (1989) Mechanisms of inhibition of DNA synthesis by 2-chlorodeoxyadenosine in human lymphoblastic cells. Cancer Res 49:6923

15. Heinemann V, Hertel LW, Grindey GB, Plunkett W (1988) Comparison of the cellular pharmacokinetics and toxicity of $2^{\prime}, 2^{\prime}$-difluorodeoxycytidine and 1- $\beta$-D-arabinofuranosylcytosine. Cancer Res 48:4024

16. Heinemann V, Xu Y-Z, Chubb S, Sen A, Hertel LW, Grindey GB, Plunkett W (1990) Inhibition of ribonucleotide reduction in CCRF-CEM cells by $2^{\prime}, 2^{\prime}$-difluorodeoxycytidine. Mol Pharmacol 38:567

17. Heinemann V, Xu Y-Z, Chubb S, Sen A, Hertel LW, Grindey GB, Plunkett W (1992) Cellular elimination of $2^{\prime}, 2^{\prime}$-difluorodeoxycytidine $5^{\prime}$-triphosphate: a mechanism of selfpotentiation. Cancer Res 52:533

18. Hendricks SP, Mathews CK (1998) Differential effects of hydroxyurea upon deoxyribonucleoside triphosphate pools, analyzed with vaccinia virus ribonucleotide reductase. J Biol Chem 273:29519

19. Hoglund L, Pontis E, Reichard P (1991) Deoxyribonucleotide metabolism in hydroxyurea-resistant V79 hamster cells. Eur J Biochem 196:239

20. Huang P, Siciliano MJ, Plunkett W (1989) Gene deletion, a mechanism of induced mutation by arabinosyl nucleosides. Mutat Res 210:291

21. Huang P, Chubb S, Hertel LW, Grindey GB, Plunkett W (1991) Action of 2',2'-difluorodeoxycytidine on DNA synthesis. Cancer Res 51:6110

22. Jordan A, Reichard P (1998) Ribonucleotide reductases. Annu Rev Biochem 67:71

23. Kufe DW, Major PP, Egan EM, Beardsley GP (1980) Correlation of cytotoxicity with incorporation of ara-C into DNA. J Biol Chem 255:8997

24. Lagergren J, Reichard P (1987) Purine deoxyribonucleosides counteract effects of hydroxyurea on deoxyribonucleoside triphosphate pools and DNA synthesis. Biochem Pharmacol 36:2985

25. Lawrence TS, Chang EY, Hahn TM, Hertel LW, Shewach DS (1996) Radiosensitization of pancreatic cancer cells by $2^{\prime}, 2^{\prime}$ difluoro-2'-deoxycytidine. Int J Radiat Oncol Biol Phys 34:867

26. Matsukage A, Ono K, Ohashi A, Takahashi T, Nakayama C, Saneyoshi M (1978) Inhibitory effect of $1-\beta$-D-arabinofuranosylthymine 5 -triphosphate and $1-\beta$-D-arabinofuranosylcytosine $5^{\prime}$-triphosphate on DNA polymerases from murine cells and oncornavirus. Cancer Res 38:3076

27. Milas L, Fujii T, Hunter N, Elshaikh M, Mason KA, Plunkett W, Ang KK, Hittelman W (1999) Enhancement of tumor radioresponse in vivo by gemcitabine. Cancer Res 59:104

28. Moore EC, Cohen SS (1967) Effects of arabinonucleotides on ribonucleotide reduction by an enzyme system from rat tumor. J Biol Chem 212:2116
29. Nocentini G (1996) Ribonucleotide reductase inhibitors: new strategies for cancer chemotherapy. Crit Rev Oncol Hematol 22:89

30. Ostruszka LJ, Shewach DS (2000) Role of ribonucleotide reductase inhibition in cytotoxicity of gemcitabine ( $\mathrm{dFdCyd})$ (abstract). Proc Am Assoc Cancer Res 41:862

31. Ostruszka LJ, Shewach DS (2000) The role of cell cycle progression in radiosensitization by $2^{\prime}, 2^{\prime}$-difluoro- $2^{\prime}$-deoxycytidine. Cancer Res 60:6080

32. Parker WB, Bapat AR, Shen J-X, Townsend AJ, Cheng Y (1988) Interaction of 2-halogenated dATP analogs (F, Cl, and $\mathrm{Br}$ ) with human DNA polymerases, DNA primase, and ribonucleotide reductase. Mol Pharmacol 34:485

33. Parker WB, Shaddix SC, Chang $\mathrm{CH}$, White LE, Rose LM, Brockman RW, Shortnacy AT, Montgomery JA, Secrist JA III, Bennett LL (1991) Effects of 2-chloro-9-(2-deoxy-2-fluoro$\beta$-D-arabinofuranosyl)adenine on K562 cellular metabolism and the inhibition of human ribonucleotide reductase and DNA polymerases by its 5'-triphosphate. Cancer Res 51:2386

34. Parker WB, Shaddix SC, Rose LM, Shewach DS, Hertel L, Secrist JA III, Montgomery JA, Bennett LL (1999) Comparison of the mechanism of cytotoxicity of 2-chloro-9-(2-deoxy-2fluoro- $\beta$-D-arabinofuranosyl)adenine, 2-chloro-9-(2-deoxy-2fluoro- $\beta$-D-ribofuranosyl)adenine, and 2-chloro-9-(2-deoxy-2, 2 -difluoro- $\beta$-D-ribofuranosyl)adenine in CEM cells. Mol Pharmacol 55:515

35. Plunkett W, Saunders PP (1991) Metabolism and action of purine nucleoside analogs. Pharmacol Ther 49:239

36. Plunkett W, Huang P, Searcy CE, Gandhi V (1996) Gemcitabine: preclinical pharmacology and mechanisms of action. Semin Oncol 23:3

37. Prusoff W, Goz B (1975) Halogenated pyrimidine deoxyribonucleosides. In: Sartorelli AC, Johns DG (eds) Handbook of experimental pharmacology. Springer-Verlag, New York, pp. 272-347

38. Reid R, Mar E-C, Huang E-S, Topal MD (1988) Insertion and extension of acyclic, dideoxy, and ara nucleotides by herpesviridae, human $\alpha$ and human $\beta$ polymerases. J Biol Chem 263:3898

39. Rockwell S, Grindey GB (1992) Effect of 2',2'-difluorodeoxycytidine on the viability and radiosensitivity of EMT6 cells in vitro. Oncol Res 4:151

40. Ross DD, Cuddy DP (1994) Molecular effects of $2^{\prime}, 2^{\prime}$-difluorodeoxycytidine (gemcitabine) on DNA replication in intact HL-60 cells. Biochem Pharmacol 48:1619

41. Ruiz van Haperen VWT, Veerman G, Vermorken JB, Peters GJ (1993) 2',2'-Difluoro-deoxycytidine (gemcitabine) incorporation into RNA and DNA of tumour cell lines. Biochem Pharmacol 46:762

42. Schy WE, Hertel LW, Kroin JS, Bloom LB, Goodman MF, Richardson FC (1993) Effect of a template-located $2^{\prime}, 2^{\prime}$-difluorodeoxycytidine on the kinetics and fidelity of base insertion by Klenow ( $3^{\prime}-5^{\prime}$ exonuclease-) fragment. Cancer Res 53:4582

43. Sheaff R, Ilsley D, Kuchta R (1991) Mechanism of DNA polymerase $\alpha$ inhibition by aphidicolin. Biochemistry 30:8590

44. Shewach DS (1992) Quantitation of deoxyribonucleoside 5'triphosphates by a sequential boronate and anion-exchange high pressure liquid chromatography procedure. Anal Biochem 206:178

45. Shewach DS, Ellero J, Mancini WR, Ensminger WD (1992) Decrease in TTP pools mediated by 5-bromo-2'-deoxyuridine exposure in a human glioblastoma cell line. Biochem Pharmacol 43:1579

46. Shewach DS, Hahn TM, Chang E, Hertel LW, Lawrence TS (1994) Metabolism of $2^{\prime}, 2^{\prime}$-difluoro-2'-deoxycytidine and radiation sensitization of human colon carcinoma cells. Cancer Res $54: 3218$

47. Sinclair WK (1968) The combined effect of hydroxyurea and X-rays on Chinese hamster cells in vitro. Cancer Res 28:198

48. Sun L-Q, Li Y-X, Guillou L, Coucke PA (1998) (E)-2'-Deoxy$2^{\prime}$-(fluoromethylene) cytidine potentiates radioresponse of two human solid tumor xenografts. Cancer Res 58:5411 
49. Szybalski W (1974) X-ray sensitization by halopyrimidines. Cancer Chemother Rep 58:539

50. Tseng WC, Derse D, Cheng Y, Brockman RW, Bennett LL (1982) In vitro biological activity of $9-\beta$-D-arabinofuranosyl-2fluoroadenine and the biochemical actions of its triphosphate on DNA polymerases and ribonucleotide reductase from HeLa cells. Mol Pharmacol 21:474

51. Xie C, Plunkett W (1995) Metabolism and actions of 2-chloro9-(2-deoxy-2-fluoro- $\beta$-D-arabinofuranosyl)-adenine in human lymphoblastoid cells. Cancer Res 55:2847 